\title{
Analysis on the Influence of Increasing Seismic Fortification Intensity on Seismic Performance of Underground Station
}

\author{
Ying Zeng $\mathbb{D}^{1},{ }^{1}$ Shiguang $X u \mathbb{D}^{1,2}$ and Shiqian Yin ${ }^{1}$ \\ ${ }^{1}$ School of Land and Resources Engineering, Kunming University of Science and Technology, Kunming 650093, China \\ ${ }^{2}$ Yunnan Geological and Mineral Bureau of Exploration \& Exploitation, Kunming 650041, China \\ Correspondence should be addressed to Shiguang Xu; xushiguang828@qq.com
}

Received 27 July 2021; Accepted 26 August 2021; Published 13 September 2021

Academic Editor: Lingkun Chen

Copyright (c) 2021 Ying Zeng et al. This is an open access article distributed under the Creative Commons Attribution License, which permits unrestricted use, distribution, and reproduction in any medium, provided the original work is properly cited.

China Earthquake Parameter Zoning (2016) has increased the seismic fortification intensity in Chengdu from VII to VIII. It is necessary to conduct in-depth discussion on the impact of the seismic performance of the built underground station structure. In this paper, a stratum-structure finite element model is established with a Chengdu subway station as an example. The model boundary adopts viscoelastic boundary, and the ground motion is input in the form of equivalent nodal force. The equivalent linearization method is used to consider the nonlinearity of soil materials. The time-history analysis of seismic fortification intensity of VII and VIII degrees is carried out, respectively. By comparing the calculation results of the two seismic fortification intensity ground motion conditions, it is concluded that the connection between the side wall and the floor is the weakest position of the station structure under the action of the earthquake; the seismic fortification intensity is increased from VII to VIII to the internal force of the structure. It has a relatively large impact, especially the most obvious impact on the bending moment. The results of the verification of the seismic time-history analysis show that the increase of fortification intensity will have a more obvious impact on the structural deformation, and the structural design of the station can meet the safety performance requirements of VII and VIII degrees of seismic fortification. The research has certain reference significance for the seismic safety evaluation of the built underground station structure in Chengdu area.

\section{Introduction}

With the development of science and technology and productivity in China, more and more underground structure projects are emerging and the research on their seismic performance is paid more and more attention [1]. Hashash et al. [2, 3], respectively, summarized the earthquake disaster phenomena, model test, and theoretical research results, as well as the present situation of earthquakeresistant analysis and design of underground structures at home and abroad; the results can be used to guide the seismic design of underground structures.

Wang et al. $[4,5]$ adopted the finite element numerical simulation method, respectively, to establish an analysis model and discuss the influence law of seismic response of underground structures. Zou et al. [6] proposed an improved finite element method, NewPSA, to predict the nonlinear behavior of underground frame structures under horizontal seismic action and a new one-dimensional seismic analysis method to calculate the distribution of displacement and shear stress along the depth in the free field with the increase of the movement of bedrock. Jiang et al. [7] proposed an improved pushover analysis method (I-PAM) and proved that I-PAM could accurately predict the maximum axial force, bending moment, and displacement of the structure. Shi et al. [8] and Yu and Yuan [9], respectively, adopted the response displacement method to discuss the applicability of the seismic analysis of underground integrated pipe corridor and complex underground large space structure, as well as the selection of foundation spring stiffness and the simulation method. Al Agha et al. [10] used ABAQUS to create soil media and used the El Centro acceleration time-history record input by seismic load to analyze the difference of the influence of buildings on 
soft soil and hard soil in strong earthquakes, and the research results have good engineering guiding significance.

Zhou et al. [11, 12] combined engineering examples, compared the differences of inertial force method, timehistory analysis method, and response displacement method in seismic analysis of underground structures, and put forward the applicability and suggestions of different calculation formulas. Deng and Liang [13] selected five calculation methods including the inertia force method, reaction displacement method, and dynamic time-history method and evaluated the adaptability of the five calculation methods. Xu et al. [14] discussed the forced reaction displacement method and the reaction acceleration method on the basis of the reaction displacement method. When the forced reaction displacement method was used, it was suggested that the side distance should be twice the width of the structure, while when the reaction acceleration method was used, the side distance should be more than three times the width of the structure. Li et al. [15] and Liu et al. [16], respectively, improved the seismic pushover analysis method of underground structures, and the two improved methods can better evaluate the seismic performance of underground structures after being verified by examples. The pushover analysis [17] was proposed for the large difference in seismic response characteristics of surface structures. It has been proved that the pushover analysis can be effectively applied to seismic design and damage assessment of underground structures.

Belostotsky et al. [18] introduced the classification and brief overview of force-based methods, displacement-based methods, and numerical methods for seismic analysis of the coupling system of soil-underground structures, providing methods and means for seismic design of underground structures. Yu et al. [19] proposed a VHS method for seismic analysis of soil-structure system using a multiaxis test device and applied it to practical projects, verifying its rationality and accuracy. Li et al. [20] set up a 3D simulation analysis model to study the seismic characteristics of cross-transfer subway station under the action of horizontal seismic waves in soft soil layer. Qiu et al. [21], based on the dynamic equilibrium characteristics of the aboveground buildingsoil-subway station integral model, proposed a simplified calculation method for the structural internal forces of subway stations.

The aseismic design of underground structure always lags behind that of aboveground structure, but underground structure is often very important; once destroyed, it is difficult to repair. Especially for underground stations, failure to do a good seismic design will cause serious danger to people's lives and property safety. Also, the cost of the underground station is high; once destroyed, the loss is very huge. Starting from June 1, 2016, new buildings in Chengdu located in the seismic fortification intensity zone of VII will be upgraded to VIII. The higher the seismic fortification intensity in an area, the stronger the overall seismic resistance of the building, which represents the requirement of an area. Therefore, it is necessary to analyze and study the impact of the increase in seismic fortification intensity on the seismic safety performance of the built subway.
This paper takes an underground station of the Chengdu Metro as an example, adopts the viscoelastic boundary and equivalent nodal force input method of ground motion, uses the equivalent linearization method to simulate its nonlinearity in the soil material, and, respectively, calculates the VII and VIII earthquake response under the conditions of high seismic fortification intensity, combined with national standards to check the seismic performance of the station structure, discuss the impact of the increase in seismic fortification intensity on the seismic performance of the built subway, and evaluate the seismic safety of the built subway project.

\section{Engineering Background}

A certain line of the Chengdu Metro was built in 2013, with a total length of $41 \mathrm{~km}$, of which the underground line is $36 \mathrm{~km}$. This study selects a typical two-storey three-span structure of the station.

The main structure of the station is $17.41 \mathrm{~m}$ high, the left and right track areas are overlapping stations, and the standard section structure has a net width of $25.50 \mathrm{~m}$. The main enclosure structure of the station adopts a $1.2 \mathrm{~m}$ thick underground continuous wall. The bottom of the station structure floor is about $21 \mathrm{~m}$ below the ground. According to the structural design, the components of the station structure that are in contact with the soil, such as the top slab (including beams), bottom plates, and side walls (including the inner columns of the wall), use C35 concrete and the components that do not contact the soil, such as the partition wall and the middle slab, use C35 concrete for the center beam and C45 concrete for the center column.

According to the geological survey report, the soil layer where the station is located is mainly silty clay and silt soil. The physical properties of the materials on the station site are sorted out as shown in Table 1. According to the "Code for Seismic Design of Buildings (GB50011-2010)" [22], the soil type of the site is comprehensively determined to be medium soft soil and the site category is Class III. The specific soil layer is shown in Table 1.

\section{Calculation Model}

The paper uses the finite element software ABAQUS to establish a two-dimensional stratum-structure model. ABAQUS is a piece of powerful universal finite element software, which includes a very rich material model, element model, load, and boundary conditions, and can solve static, dynamic, and other issues, in particular, the ability to solve nonlinear problems is very excellent for seismic dynamic analysis. The model is shown in Figure 1. The model is $100 \mathrm{~m}$ high and $200 \mathrm{~m}$ long (the distance from the structure boundary to the model boundary is more than three times the width of the structure). The grid is divided into plane strain units, in which the soil is divided into 37621 units, and the station structure is divided into 3236 units.

The calculation model in this paper adopts the viscoelastic boundary, and the ground motion input adopts the equivalent nodal force, that is, the spring-damping system 
TABLE 1: Soil material parameters.

\begin{tabular}{|c|c|c|c|c|c|}
\hline Soil layer number & Soil & Layer thickness $(\mathrm{m})$ & Density $\left(\mathrm{kg} \cdot \mathrm{m}^{3)}\right.$ & Wave speed $\left(\mathrm{m} \cdot \mathrm{s}^{-1}\right)$ & Poisson's ratio \\
\hline 1 & Plain fill & 1.50 & 1916.2 & 107.0 & 0.429 \\
\hline 2 & Silty clay & 3.50 & 1953.7 & 138.0 & 0.429 \\
\hline 3 & Clay & 5.85 & 1909.6 & 126.5 & 0.410 \\
\hline 4 & Silty clay & 3.45 & 1966.3 & 165.0 & 0.429 \\
\hline 5 & Clay & 1.40 & 2019.5 & 206.0 & 0.418 \\
\hline 6 & Silty clay & 4.25 & 2033.9 & 240.0 & 0.425 \\
\hline 7 & Silty clay & 2.35 & 2020.6 & 266.0 & 0.417 \\
\hline 8 & Clay & 4.65 & 2053.1 & 257.3 & 0.412 \\
\hline 9 & Clay & 1.50 & 2060.4 & 250.0 & 0.339 \\
\hline 10 & Clay & 2.75 & 2045.3 & 267.5 & 0.402 \\
\hline 11 & Silty clay & 8.10 & 2005.8 & 243.0 & 0.411 \\
\hline 12 & Clay & 2.85 & 2056.3 & 367.0 & 0.412 \\
\hline 13 & Silty clay & 2.50 & 2018.5 & 250.0 & 0.428 \\
\hline 14 & Clay & 10.45 & 2001.6 & 376.5 & 0.422 \\
\hline 15 & Clay & 10.30 & 2045.3 & 312.0 & 0.412 \\
\hline 16 & Clay & 7.00 & 2091.2 & 318.0 & 0.412 \\
\hline 17 & Silty clay & 7.50 & 2074.1 & 334.0 & 0.412 \\
\hline 18 & Clay & 4.00 & 2065.3 & 329.0 & 0.422 \\
\hline 19 & Silty clay & 4.50 & 2077.4 & 339.0 & 0.432 \\
\hline 20 & Silty clay & 4.00 & 1957.2 & 450.0 & 0.422 \\
\hline
\end{tabular}

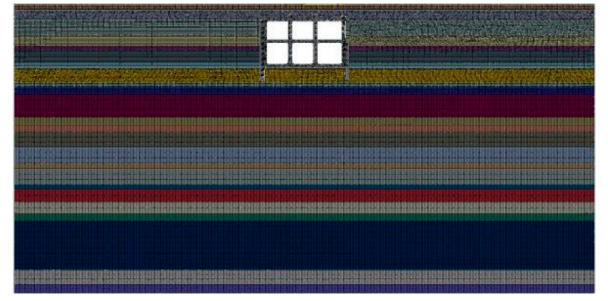

Figure 1: Finite element meshing of the formation-structure model.

and the equivalent nodal force are applied at the model boundary. The spring element is used to simulate the elastic recovery ability of the soil, and the damping element is used to absorb the scattered wave energy at the boundary, as shown in Figure 2. The equivalent nodal force is calculated from the velocity, displacement, and stress of the free field, which is used to simulate the input of ground motion.

In this paper, the equivalent linearization method is used to simulate the nonlinear characteristics of soil materials. According to the geological survey report, the relationship between the dynamic shear modulus ratio, damping ratio, and shear strain of soil materials is shown in Table 2 .

The ground motion input of the calculation model adopts the VII degree fortified ground motion of the station design and the VIII degree fortified ground motion of the adjacent project. The ground motion time-history curve is shown in Figures 3(a) and 3(b). The peak ground accelerations of $E 1, E 2$, and $E 3$ are $0.052 \mathrm{~g}, 0.178 \mathrm{~g}$, and $0.314 \mathrm{~g}$ for VII degree and $0.042 \mathrm{~g}, 0.148 \mathrm{~g}$, and $0.380 \mathrm{~g}$ for VIII degree, respectively.

\section{Result Analysis}

The impact of the increase in seismic fortification intensity on the seismic performance of underground stations is reflected in three aspects: structural internal force, seismic performance index check calculations, and suggested measures.

4.1. Internal Force of Structure. Taking the E3 seismic condition calculated by the seismic fortification intensity of VIII degree as an example, the displacement and strain cloud diagrams at the moment of maximum bending moment of the station structure are given in Figures 4(a) and 4(b).

It can be seen from Figure 4(a) that the horizontal displacement of the station structure is relatively large, reaching about $0.66 \mathrm{~m}$, which is the result of coordinated deformation with the soil. However, the relative displacement of the top and bottom of the station is not large. At the moment of maximum bending moment, the maximum relative displacement of the top and bottom of the station is $12.4 \mathrm{~mm}$. Figure 4(b) shows that the location of the most adverse effect of ground motion on the station structure is at the connection between the side wall and the bottom plate, which needs to be paid attention to in the seismic design. Generally, the side wall and bottom plate of the station can be thickened or the concrete strength level can be increased.

The axial force, shear force, and bending moment of the station structure at the maximum moment of the bending moment of the station structure under the action of $E 2$ and 


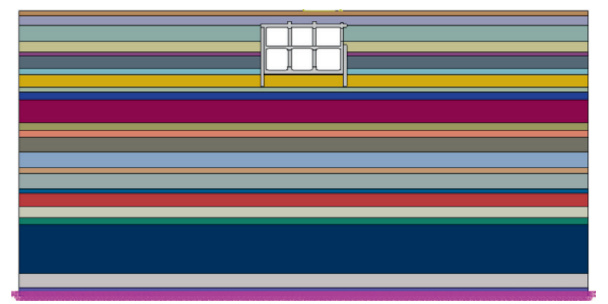

Figure 2: The viscoelastic boundary in the formation-structure model.

TABle 2: Relationship between dynamic shear modulus ratio, damping ratio, and shear strain.

\begin{tabular}{|c|c|c|c|c|c|c|c|c|c|c|}
\hline \multirow{2}{*}{ Soil } & \multirow{2}{*}{ Depth (m) } & \multirow{2}{*}{ Experimental results } & \multicolumn{8}{|c|}{ Shear strain } \\
\hline & & & $5 \times 10^{-6}$ & $1 \times 10^{-5}$ & $5 \times 10^{-5}$ & $1 \times 10^{-4}$ & $5 \times 10^{-4}$ & $1 \times 10^{-3}$ & $5 \times 10^{-3}$ & $1 \times 10^{-2}$ \\
\hline \multirow{2}{*}{ Silty clay } & \multirow{2}{*}{9.2} & $G / G_{0}$ & 0.9859 & 0.9958 & 0.9652 & 0.9235 & 0.777 & 0.5478 & 0.1744 & 0.1075 \\
\hline & & $\lambda_{d}$ & 0.0245 & 0.0383 & 0.0554 & 0.0694 & 0.117 & 0.137 & 0.1759 & 0.1755 \\
\hline \multirow{2}{*}{ Silty clay } & \multirow{2}{*}{20.5} & $G / G_{0}$ & 0.9969 & 0.9988 & 0.9654 & 0.9248 & 0.7070 & 0.5480 & 0.1752 & 0.1081 \\
\hline & & $\lambda_{d}$ & 0.0185 & 0.0282 & 0.04542 & 0.0478 & 0.1001 & 0.1176 & 0.1519 & 0.1550 \\
\hline \multirow{2}{*}{ Silt sand } & \multirow{2}{*}{32.5} & $G / G_{0}$ & 0.9973 & 0.9986 & 0.9543 & 0.941 & 0.7277 & 0.5775 & 0.2129 & 0.1155 \\
\hline & & $\lambda_{d}$ & 0.0177 & 0.0285 & 0.0453 & 0.0594 & 0.0973 & 0.1778 & 0.1485 & 0.1559 \\
\hline \multirow{2}{*}{ Silty clay } & \multirow{2}{*}{46.3} & $G / G_{0}$ & 0.9866 & 0.9982 & 0.957 & 0.9361 & 0.7474 & 0.5941 & 0.2266 & 0.1577 \\
\hline & & $\lambda_{d}$ & 0.0187 & 0.0287 & 0.0453 & 0.0609 & 0.1076 & 0.1279 & 0.1687 & 0.1665 \\
\hline \multirow{2}{*}{ Silt } & \multirow{2}{*}{65.3} & $G / G_{0}$ & 0.9864 & 0.9988 & 0.9548 & 0.932 & 0.7726 & 0.577 & 0.216 & 0.1206 \\
\hline & & $\lambda_{\mathrm{d}}$ & 0.0288 & 0.0288 & 0.0559 & 0.065 & 0.1073 & 0.1284 & 0.1616 & 0.1668 \\
\hline \multirow{2}{*}{ Silty clay } & \multirow{2}{*}{78.0} & $G / G_{0}$ & 0.986 & 0.982 & 0.9655 & 0.9258 & 0.7179 & 0.5571 & 0.1996 & 0.1106 \\
\hline & & $\lambda_{d}$ & 0.0188 & 0.0282 & 0.0415 & 0.0561 & 0.1037 & 0.1771 & 0.1666 & 0.1644 \\
\hline
\end{tabular}

E3 seismic fortification intensity of VII and VIII degrees are extracted, respectively, as shown in Table 3.

Table 3 compares the influence of the increase in seismic fortification intensity on the internal force of the station structure. Under the action of E2 ground motion, the increase in seismic fortification intensity increased the internal force of the structure by 16\% 23\%; under the action of E3 ground motion, the increase in seismic fortification intensity had a more obvious impact on the internal force of the structure, and the internal force of the structure increased by $20 \% \sim 30 \%$. The increase in seismic fortification intensity has a greater impact on the bending moment of the structure, which is more obvious in the working conditions of E3 ground motion. The comparison of the structural internal forces of the seismic fortification intensity of VII and VIII degrees shows that the influence of seismic fortification intensity on the structure of the built underground station cannot be ignored, and attention should be paid to the design of seismic safety performance.

\subsection{Checking Calculation of Seismic Performance Index.} According to the "Standard for Seismic Design of Underground Structures" [23], the calculation results are checked for cross-sectional bearing capacity and seismic deformation. Among them, the cross-sectional bearing capacity is reflected by the area of cross-sectional reinforcement and the seismic deformation is reflected by the displacement angle between floors.

It can be seen from Table 4 that, (1) in the case of fortification of degree VII, compared with the calculation results under the action of moderate earthquake E2, the effect of large earthquake E3 increased the area of reinforcement by $18.1 \%$ and the displacement angle between floors increased by $15.2 \%$; (2) in the case of fortification of degree VIII, compared with the results of the calculation under the action of the moderate earthquake E2, the effect of the large earthquake $E 3$ increased the reinforcement area by $11.3 \%$ and the interstorey displacement angle by $30.5 \%$. The effect of the strong earthquake E3 has increased the displacement angle between floors more than the increase of the reinforcement area, indicating that the structure has entered the elastoplastic stage under the effect of the strong earthquake E3. The increase in fortification intensity has significantly improved the internal force and deformation check calculation indicators, so the impact of the increase in seismic fortification intensity on the seismic performance of underground stations should be given sufficient attention. (3) The increase in seismic fortification intensity increased the area of reinforcement under the action of moderate earthquake $E 2$ by about $33.8 \%$, and the displacement angle between floors increased by about $47.8 \%$; the area of reinforcement under the action of large earthquake $E 3$ needed to be increased by about $26.1 \%$. The displacement angle between layers increased by about $67.4 \%$. The reinforcement area reflects the change in the internal force of the structure, and the displacement angle between floors reflects the change in the structural deformation. It is not difficult to see that the increase in seismic fortification intensity has a considerable impact on the structural deformation, which deserves special attention in future engineering practice.

The checked calculation results show that the structural design of the station can meet the safety performance requirements of degree VII and degree VIII seismic fortification. 


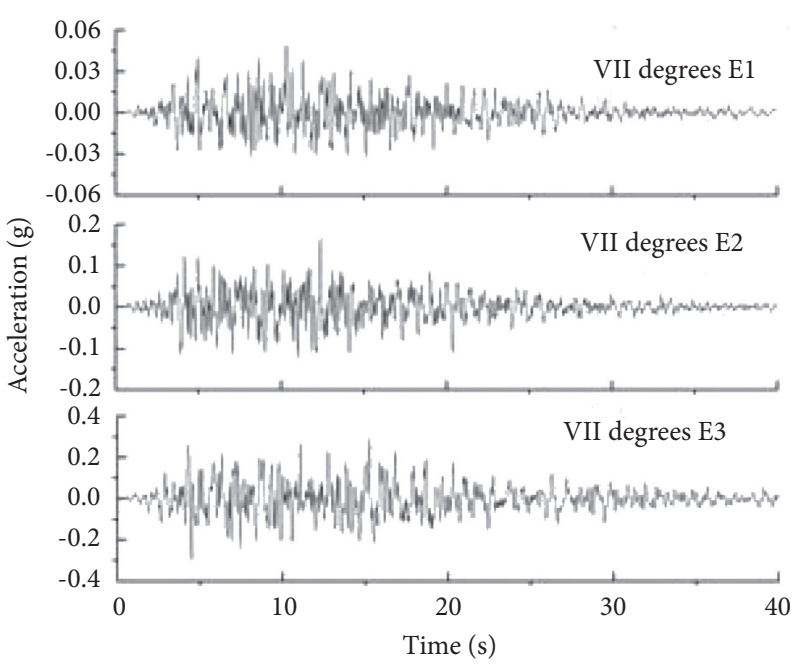

(a)

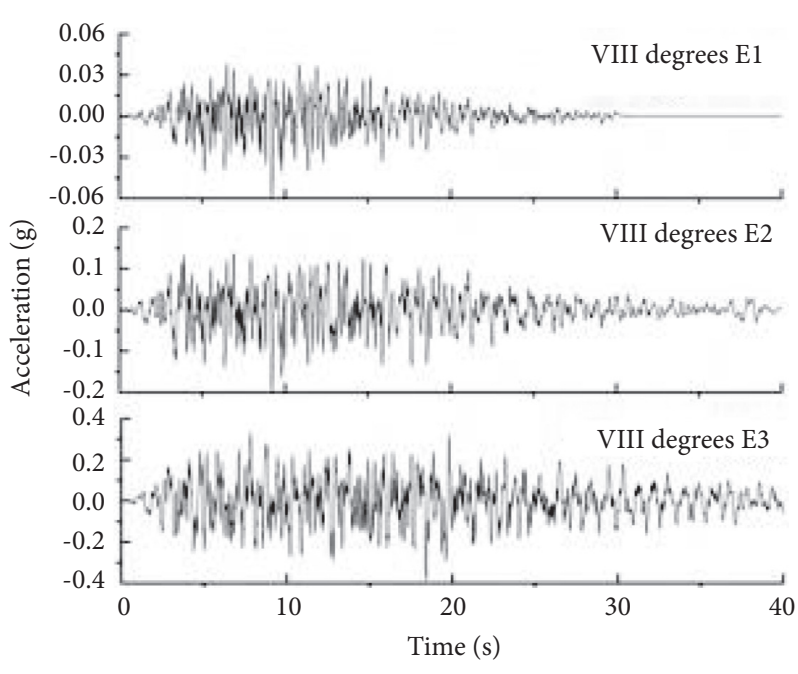

(b)

FIGURE 3: The time-history curve of bedrock motion with seismic fortification intensity. (a) VII degree. (b) VIII degree.

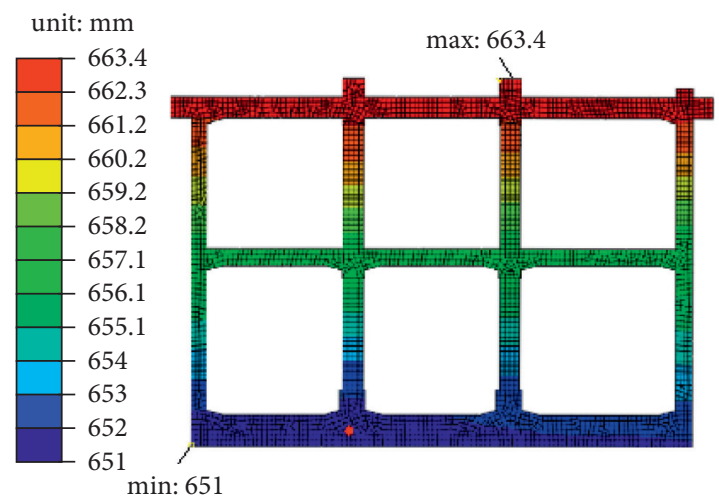

(a)

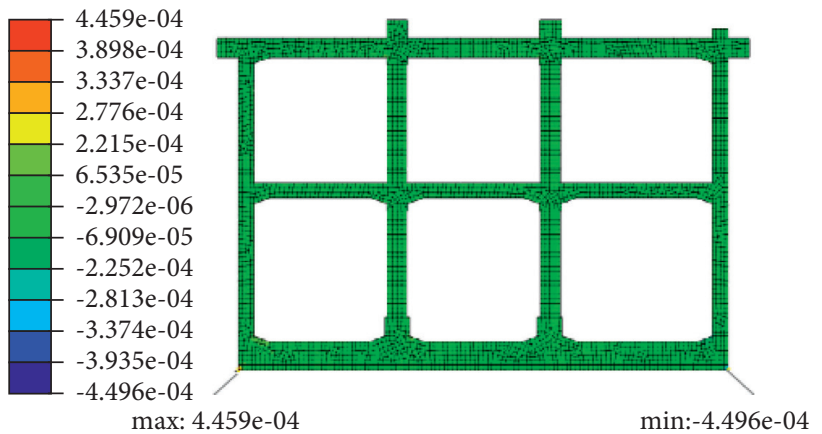

(b)

FIgURE 4: (a) The horizontal displacement and (b) the shearing strain of the station with the E3 earthquake motion of degree VIII.

TABLE 3: Internal forces of the station structure with different earthquake motions.

\begin{tabular}{|c|c|c|c|c|c|c|}
\hline \multirow[b]{2}{*}{ Type } & \multicolumn{3}{|c|}{$E 2$} & \multicolumn{3}{|c|}{ E3 } \\
\hline & $\begin{array}{l}\text { VII degree } \\
\text { fortification }\end{array}$ & $\begin{array}{l}\text { VIII degree } \\
\text { fortification }\end{array}$ & $\begin{array}{c}\text { Difference } \\
\%\end{array}$ & $\begin{array}{l}\text { VII degree } \\
\text { fortification }\end{array}$ & $\begin{array}{l}\text { VIII degree } \\
\text { fortification }\end{array}$ & $\begin{array}{c}\text { Difference } \\
\%\end{array}$ \\
\hline Axial force $(\mathrm{kN})$ & 991.3 & 1182.5 & 19 & 1296.5 & 1687.1 & 30 \\
\hline Shear force $(\mathrm{kN})$ & 968.7 & 1123.8 & 16 & 1212.8 & 1451.4 & 20 \\
\hline $\begin{array}{l}\text { Bending moment } \\
(\mathrm{kN} \cdot \mathrm{m})\end{array}$ & 1542.3 & 1896.5 & 23 & 1968.7 & 2469.2 & 25 \\
\hline
\end{tabular}

TABLE 4: Checking calculation results of section bearing capacity and deformation.

\begin{tabular}{lccccc}
\hline Type & $\begin{array}{c}\text { Design } \\
\text { value }\end{array}$ & $\begin{array}{c}\text { VII degree } \\
\text { fortification }\end{array}$ & $\begin{array}{c}\text { VIII degree } \\
\text { fortification }\end{array}$ & $\begin{array}{c}\text { VII degree } \\
\text { fortification }\end{array}$ & $\begin{array}{c}\text { VIII degree } \\
\text { fortification }\end{array}$ \\
\hline $\begin{array}{l}\text { Reinforcement area } \\
\left(\mathrm{mm}^{2}\right)\end{array}$ & $\begin{array}{c}4765.6 \\
\text { Layer displacement angle }\end{array}$ & $\begin{array}{c}E 2<1 / 600 \\
E 3<1 / 300\end{array}$ & $1 / 1360$ & 2961.5 & 2614.8 \\
\\
\hline
\end{tabular}




\section{Conclusion}

In this paper, a stratum-structure model is established by taking the structure of a certain subway station in Chengdu as an example. The nonlinearity of soil materials is simulated by using the equivalent linearization method, the finite element analysis model is based on viscoelastic boundary, and the ground motion is input in the form of equivalent nodal force. Through seismic time-history analysis, the effect of the increase in seismic fortification intensity on the seismic performance of the station is comparatively studied, and the calculation results are checked according to the national standards, and the following conclusions are drawn:

(1) The most unfavorable position of the effect of ground motion on the structure of the underground station is at the connection between the side wall and the bottom plate. At the stage of seismic design, attention should be paid to the strengthening design of this position. Generally, the side wall and bottom plate of the station can be thickened or the concrete strength level can be increased.

(2) The impact of the increase in seismic fortification intensity on the internal force of the built underground station structure cannot be ignored, especially the impact on the structural bending moment is more obvious. According to the data analysis in this paper, the increase of seismic fortification intensity has a considerable impact on the structural deformation, such as in the E3 earthquake, the reinforcement rate increased by $26.1 \%$, increasing the material consumption and cost of underground construction.

(3) The calculation results checked according to the national standards show that the increase in fortification intensity will have a more obvious impact on structural deformation; the structural design of the station can meet the safety performance requirements of degree VII and degree VIII seismic fortification.

\section{Data Availability}

The data are generated from experiments and can be made available by the corresponding author upon request.

\section{Conflicts of Interest}

The authors declare that there are no conflicts of interest regarding the publication of this paper.

\section{Authors' Contributions}

Ying Zeng carried out the experiments, analyzed the results, conducted the theoretical explanations, and wrote the manuscript. Shiguang Xu provided constructive suggestions and performed significant review and editing of the technical paper. Shiqian Yin provided rigor and fluency in the language of the academic paper.

\section{References}

[1] Y. M. A. Hashash, "Seismic behavior of underground structures and site response," in Earthquake Engineering Frontiers in the New Millennium, pp. 243-249, CRC Press, Beijing,China, 2000.

[2] Y. M. A. Hashash, J. J. Hook, B. Schmidt, and J. I-Chiang Yao, "Seismic design and analysis of underground structures," Tunnelling and Underground Space Technology, vol. 16, no. 4, pp. 247-293, 2001.

[3] X. Yao, "Seismic response analyses method of underground structures in China," in Proceedings of the 2015 International Forum on Energy, Environment Science and Materials, pp. 309-314, Shenzhen, China, September 2015.

[4] X. J. Wang, H. Y. Zhuang, G.-X. Chen, and R. Wang, "Effect of diaphragm wall on earthquake responses of an underground subway stationJournal of Geotechnical Engineering," Chinese Journal of Geotechnical Engineering, vol. 39, no. 8, pp. 1435-1443, 2017.

[5] W. H. Gao and X. Ji, "A three-dimensional finite element dynamic model for seismic behavior of rail transit structures in the urban underground space," China Earthquake Engineering Journal, vol. 41, no. 2, pp. 347-352, 2019.

[6] Y. Zou, H. Liu, L. Jing, and J. Cui, "A pseudo-static method for seismic responses of underground frame structures subjected to increasing excitations," Tunnelling and Underground Space Technology, vol. 65, pp. 106-120, 2017.

[7] J. W. Jiang, C. S. Xu, H. M. El Naggar, X. Du, Z. Xu, and J. Assaf, "Improved pushover method for seismic analysis of shallow buried underground rectangular frame structure," Soil Dynamics and Earthquake Engineering, vol. 140, 2021.

[8] Y. Z. Shi, J. B. Hua, and X. F. Li, "Application of response displacement method in seismic design of underground utility tunnels," Journal of Jilin University. Earth Science Edition, vol. 48, no. 6, pp. 1785-1796, 2018.

[9] H. T. Yu and Y. Yuan, "Application of response displacement method on seismic design of a complex underground structure," Chinese Journal of Underground Space and Engineering, vol. 7, no. 5, pp. 857-862, 2011.

[10] W. Al Agha, W. Alozzo Almorad, N. Umamaheswari, and A. Alhelwani, "Study the seismic response of reinforced concrete high-rise building with dual framed-shear wall system considering the effect of soil structure interaction," Materials Today: Proceedings, vol. 43, no. 1, pp. 2182-2188, 2021.

[11] J. Zhou, P. Zhong, and Y. Chi, "Research on seismic soil pressure of underground structures in soft soils," Rock and Soil Mechanics, vol. 25, no. 4, pp. 554-559, 2004.

[12] Z. F. Dong, B. Z. Cai, and Y. C. Yao, "Accuracy of the response acceleration method and response displacement method considering different imbedding depths of underground structures," Journal of Vibration and Shock, vol. 36, no. 14, pp. 216-220, 2017.

[13] Y. J. Deng and F. Y. Liang, "Comparison of calculation methods for seismic response of underground structures in design codes," China Earthquake Engineering Journal, vol. 40, no. 5, pp. 996-1003, 2018.

[14] K. P. Xu, L. P. Jing, and J. Bin, “A comparative analysis of forced displacement and response acceleration methods for underground structures," China Earthquake Engineering Journal, vol. 42, no. 4, pp. 967-972, 2020.

[15] S. T. Li, J. B. Liu, X. Bao, D. Wang, and F. Wang, "Seismic analysis of underground structures based on local deformation of the free field via the pushover analysis method," China 
Earthquake Engineering Journal, vol. 41, no. 6, pp. 1472-1481, 2019.

[16] J. B. Liu, X. Q. Liu, and B. Li, "A pushover analysis method for seismic analysis and design of underground structures," China Civil Engineering Journal, vol. 41, no. 4, pp. 73-80, 2008.

[17] J. Liu, W. Wang, and G. Dasgupta, "Pushover analysis of underground structures: method and application," Science China Technological Sciences, vol. 57, no. 2, pp. 423-437, 2014.

[18] A. M. Belostotsky, P. A. Akimov, and D. D. Dmitriev, "About methods of seismic analysis of underground structures," International Journal for Computational Civil and Structural Engineering, vol. 14, no. 3, pp. 14-25, 2018.

[19] H. T. Yu and Y. X. Li, "Virtual hybrid simulation method for underground structures subjected to seismic loadings," Tunnelling and Underground Space Technology, vol. 110, 2021.

[20] Y. Li, H. Di, S. Zhou, and Q. Gong, "Seismic analysis for cross transfer subway stations in soft soil stratum," Ksce Journal of Civil Engineering, vol. 25, no. 5, pp. 1732-1745, 2021.

[21] Y. Qiu, H. Zhang, and Z. Yu, "A seismic design method of subway stations affected by surrounding buildings," Rock and Soil Mechanics, vol. 42, no. 5, pp. 1443-1452, 2021.

[22] GB50011-2010, Code for Seismic Design of Building, China Architecture and Building Press, Beijing, China, 2016.

[23] GB/T51336-2018, Standard for Seismic Design of Underground Structures, China Architecture and Building Press, Beijing, China, 2018. 